\title{
FOREIGN DIRECT INVESTMENT AND THEIR IMPACT ON MACEDONIAN ECONOMY
}

\author{
Kajdafe Ademi- State University of Tetovo, Economic Faculty \\ Muhamed Ademi- Freelancer
}

\begin{abstract}
Foreign Direct Investments are a very crucial factor on economic development to a given developing country. Recently, according to the data issued by OECD, there is down turning point in this indicator in the global level. In the case of Macedonia are taken several major investing countries and their investments are compared starting from 2010 to recently, the data are quarterly. Some countries have the so-called divestment procedure done more than the others. The paper attempts to give answer to the question why this is the case. As all of the other countries Macedonia's GDP is more dependent on the consumption. The brut investments are the last component with the smaller proportion of the total GDP. Imports and exports cointegrate but they are not cointegrated with a coefficient close to one. Even though the main growth theory suggests that economic growth is dependent more of capital, human and soil recourses there is also a proof that the productivity is the main component.FDI are not well managed and surely the mother countries of these investments are not behaved with full responsibility on implementing them. Methods used here are statistical and comparative.
\end{abstract}

Keywords: divestment, economic growth, FDI, Macedonian economy, cointegration 


\section{Introduction}

According to OECD report, overall flaws of FDI in 2017 fell for 18\% compared to that of the 2016. In 2017 the total FDI globally was estimated to be 1,401 billion dollars. From this very report we can also stress that since the 2013 the fourth quarter of 2017 had the lowest value of the FDI. FDI s are very important deal in the economy, especially for the countries in the transition. North Macedonia has faced a lot of political, social andeconomic challenges and thus this country had a variety of obstacles which led to FDI inflow fluctuations. The European Commission Report in 2018 showed a lot of problems and weaknesses but on the other hand there are mentioned some improvements that are made in some law and economic fields. Concerning the economy this report stresses out that North Macedonia should pay attention to "developing a medium-term budget framework and pursuing fiscal consolidation including by better targeting of transfer spending, improving contract enforcement and reducing informality and enhancing labor market participation and employment, especially for women and youth".

If we consider the last Fall Economic Report for Western Balkans by World Bank, we would notice that North Macedonia had, during the 2018, the lowest growth rate of GDP. The leaders in growth were Albania and Kosovo, followed by Montenegro. This will after be discussed even more analyzing the data taken into consideration.Standard \& Poor's credit rating for Macedonia is BB- with stable outlook, alsoFitch's credit rating for Macedonia was last reported at BB with positive outlook. This is improvement considering the rating form the 2016 when Fitch rated Macedonia with negative outlook.

\section{Comparison of data}

If we observe closely the Figure 1 we see a lot of changes and interesting facts. Countries that are made comparison to are our neighbors and these countries have faced similar problems being those social or political. Albania, Bosnia and Herzegovina, Kosovo, Montenegro and Serbia in the Figure 1 have series compared along with Macedonia, the data are anualy from 2000 to 2017. The small dots that are on the left corner of each graph show the values of the respective series in the year of 1990. Sadly, for most of the country's 1990 data miss.

The graph for final expenditure growth shows that all the countries face lowering of this rate, being Montenegro the country with the biggest expenditure growth rate, followed by Albania and Kosovo. Macedonia in this graph is the last.

The graph for FDI s, inflows, outflows and net FDI all show that Serbia is the most favored to foreign investors when it comes to investments, followed by Albania.Macedonia and Kosovo seem to have struggled with FDI inflows. It is very interesting that North Macedonia in the 2017 had increasing value of FDI outflows, bigger than Serbia. The inflows of FDI for most of the countries do not exceed even the 100-million-euro value.

Serbia and Kosovo for now have bigger growth rates of GDP, Macedonia again is the last one in this, even though in the 2018 the country showed some improvements. GDP per capita 
growth rate is also showing that Serbia seem to converge more rapidly than any other country taken into consideration in these graphs.

\section{FDI and growth in Macedonia- analyzing the data}

What are FDIs? Foreign Direct Investment are investment that are made by one country in another one, or we could say that FDI are investments made with foreign money. This means that the capital in mother country increases without having it to provide the main resources to start for example a business or something else related to business. FDI can be inflows or outflows and net FDI are difference between the FDI outflows and FDI inflows. As we can see from the corresponding figure, Macedonia in 2017 has had two consecutive quartal decrease in FDI, Figure2. Furthermore, it is clearly that the FDI inflows in Macedonia do not have trend, since the series is stationary. For the period being reviewed the highest value of investment is shown in 2010, around 200 million dollars.

In the Figure 3 we can observe some of the countries that have invested in Macedonia and how their investments changed during the period taken into consideration. Figure 4 however shows the comparison of each country FDI inflow and from this we can see that more noticeably is the FDI inflow of Switzerland in 2014, and divestment of France in the same year and quarter as Switzerland and even bigger amount of divestment of France in 2015.

Now let's see what is the correlation coefficient between series of real GDP growth, and FDI of North Macedonia. It is necessary to underline the fact that the series that are taken for regression analysis are not long and they are quarterly series considering the period from 2010 until 2017, so overall there are 31 data. The correlation between growth rate of real GDP and FDI is like -0.485 . What does it mean? It means that these two variables are correlated linearly about $49 \%$ but negatively. When FDI increases, growth decreases.

Table 1-Coefficient of correlation between growth rate and FDI of North Macedonia

\begin{tabular}{|c|c|r|}
\hline & FDI & GROWTH \\
\hline FDI & 1.000000 & -0.485227 \\
\hline GROWTH & -0.485227 & 1.000000 \\
\hline
\end{tabular}

Furthermore, there is done regression analysis to see if the growth could be predicted when we know the FDI. As are shown in the Table 2 the estimated coefficients and tests for signification indicate that FDI has not statistically significant coefficient but the model lacks other independent variables. Coefficient of determination is quiet low, it is not even 1 percent. It was very hard to find quarterly data for other series for the taken period, there were needed quarterly data for the unemployment series, or either population growth and of course the rate of savings. If these variables were in the model, we could see the true effect of the FDI on the growth. However, still there is the negative correlation that bonds these two series and that is not good news for North Macedonia. It is very important to mention that the model is done after the series have been seasonally adjusted since we have quarterly seasonal data. 
Table 2- Output for regression estimation coefficient for growth rate as dependent variable on FDI of North Macedonia

Coefficient

\begin{tabular}{r|l} 
Growth rate & \\
FDI & -0.000403 \\
Constant & 1.1451
\end{tabular}

t-stat (p-value)

$-0.055(0.9596)$

$2.089(0.0456)$

Let us leave a little bit the FDI and analyze the graph of real GDP and its components measured with expenditure approach, Figure 5. It is very interesting to see these features in this figure:

- Consumer spending is the most prevalent component

- Imports are the second most anticipated component

- Exports come after the import but surely these two series are far apparat of each other even though they have same shocks and changes

- Brut investments are the second last component

- Government spending are the lower value series considering the whole period

- During the period considered there are no changes in the weigh of the components to the total GDP level

- Imports are getting closer to the consumer spending,

- Government spending is not showing any trends in the considered period.

We have done some cointegration analysis of exports and imports and Real GDP. The cointegration is done with Johansen test and those are the following results:

Unrestricted Cointegration Rank Test (Trace)

\begin{tabular}{ccccc}
\hline \hline $\begin{array}{c}\text { Hypothesized } \\
\text { No. of CE(s) }\end{array}$ & Eigenvalue & $\begin{array}{c}\text { Trace } \\
\text { Statistic }\end{array}$ & $\begin{array}{c}0.05 \\
\text { Critical Value }\end{array}$ & Prob.** \\
\hline \hline None & 0.376118 & 21.84129 & 29.79707 & 0.3074 \\
At most 1 & 0.264327 & 8.631051 & 15.49471 & 0.4006 \\
At most 2 & 0.001282 & 0.035909 & 3.841466 & 0.8497 \\
\hline \hline
\end{tabular}

Trace test indicates no cointegration at the 0.05 level

* denotes rejection of the hypothesis at the 0.05 level

**MacKinnon-Haug-Michelis (1999) p-values

Source: Authors calculations done with EViews

When series cointegrate they show that they are in the long run equilibrium. In the case of North Macedonia these series do not cointegrate this means that growth is not relied on exports nor imports, furthermore the trade deficit is large meaning that the imports do not 
approach the exports and thus country is more buying from foreign countries than it is selling to them.

\section{Conclusion}

What we can conclude form the above analysis is that Macedonia is having a hard time to face with in the following periods. The political problems led to the falling of the FDI, growth rate, expenditure rate and even bigger trade deficit. These economic indicators are tied up and they affect one another consecutively. North Macedonia is relied on import- growth theory. As we saw before its imports are lately getting close to the consume spending. This is not the best solution for a country that has been so much through social, political and economic problems. Brut investments are the last category in the value of the GDP, this is the main problem. All of the governments never had a strategy on how to fix the problem with the investments, even though there was implemented the flat tax law.

The problem of the FDI is visible, the country has done so much damage when permitted some of the foreign investors to come and to stimulate with benefits. The negative correlation between FDI and real growth rate should be very concerning. This means that investors come into our country and take from us thus lowering our growth rate and GDP per capita. Mentioning the last one brings us to the problem that North Macedonia is the last country that is converging economically in the region.

There is urgently needed stricter laws and control on the foreign investors, since they are draining our economic potential and doing more harm than benefit. 


\section{Appendix}

Figure 1-Series of macroindicators for 6 countries

Final consumption expenditure (annual \% growth)

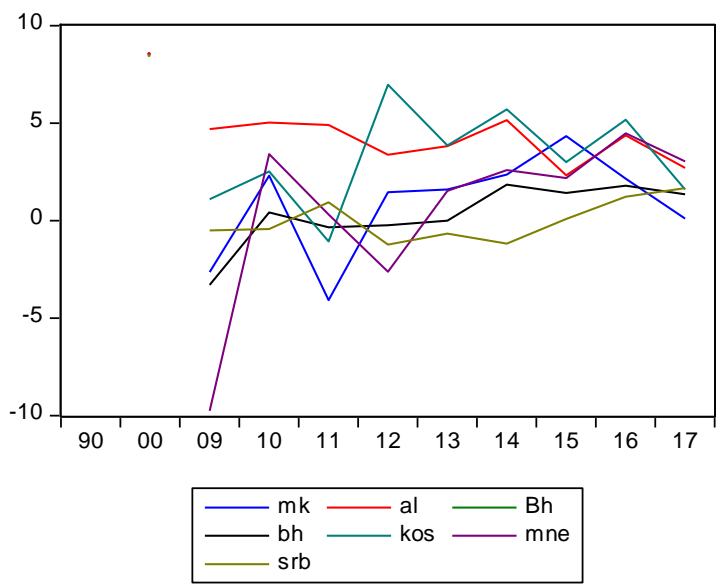

Foreign direct investment, net outflows (BoP, current US\$)

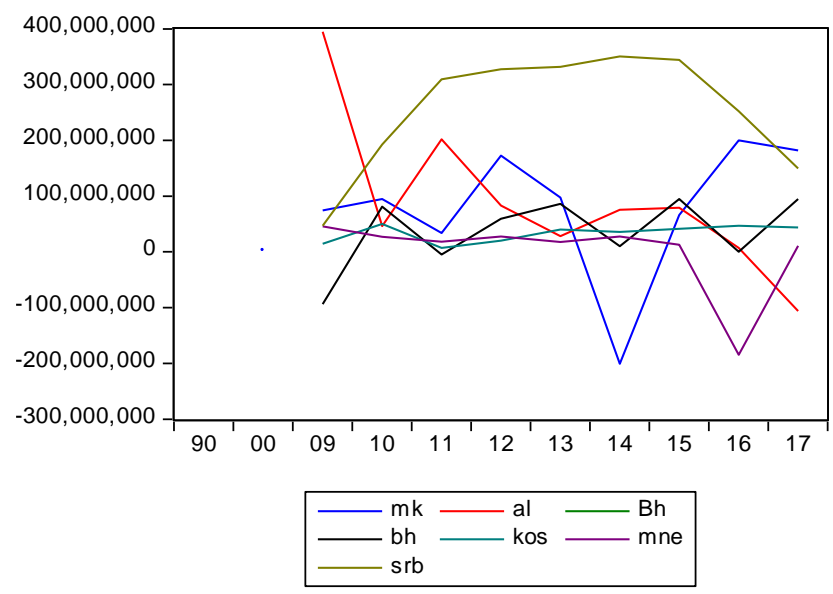

GDP growth (annual \%)
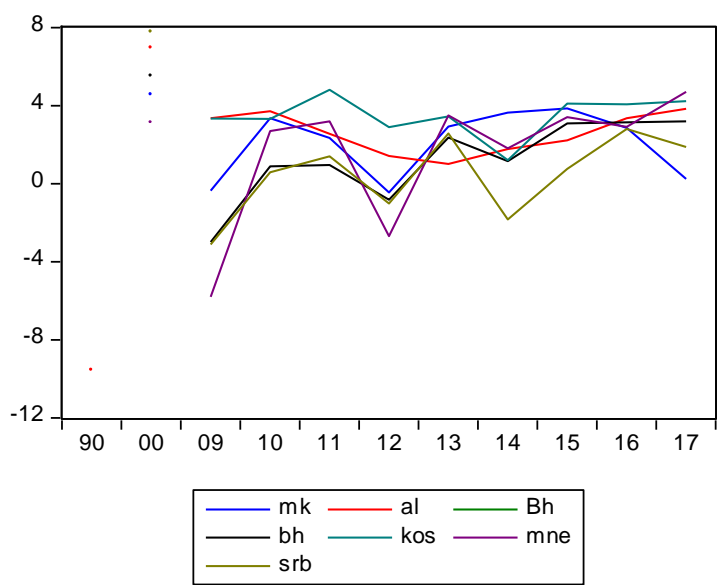

Foreign direct investment, net (BoP, current US\$)

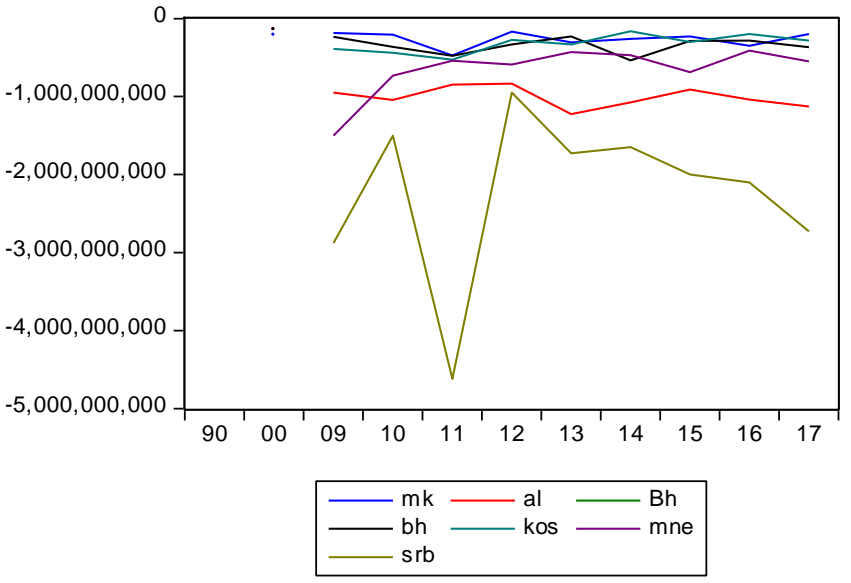

Foreign direct investment, net inflows (BoP, current US\$)

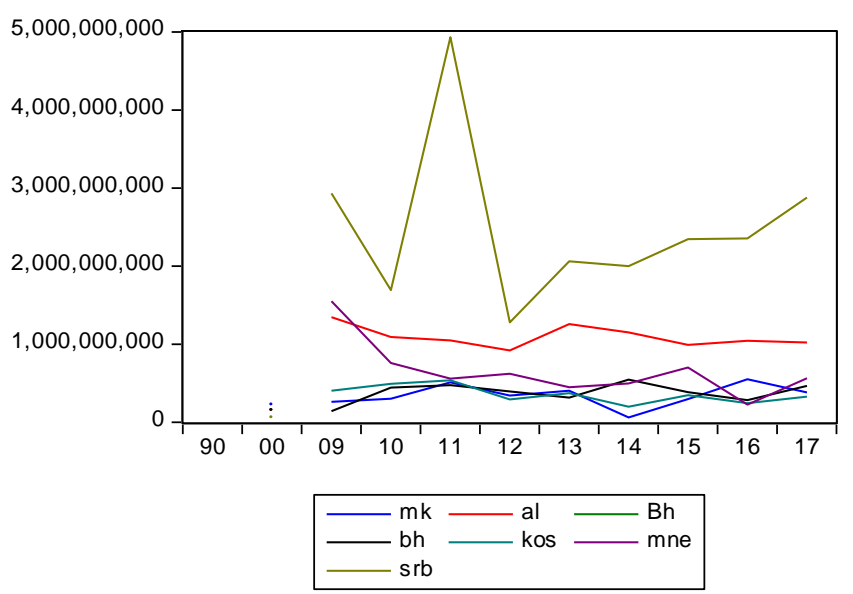

GDP per capita growth (annual \%)

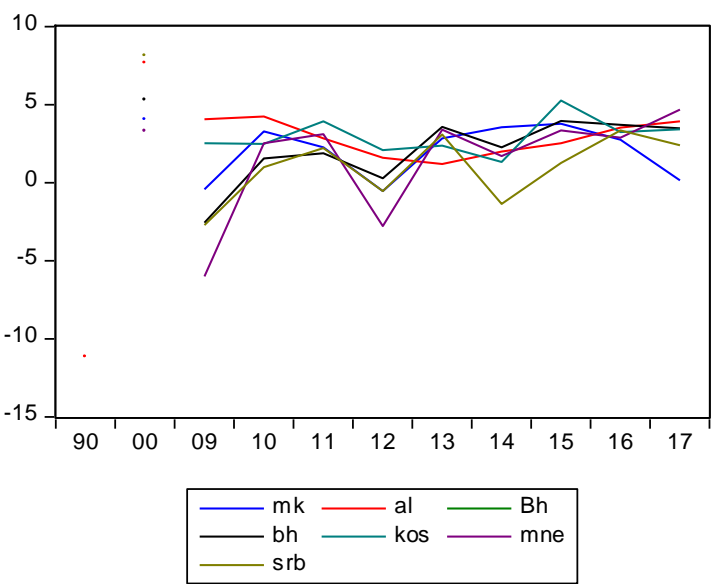

source: https://databank.worldbank.org/data/ 
Figure 2-Individual graphs for countries which are the main source of FDI in North Macedonia
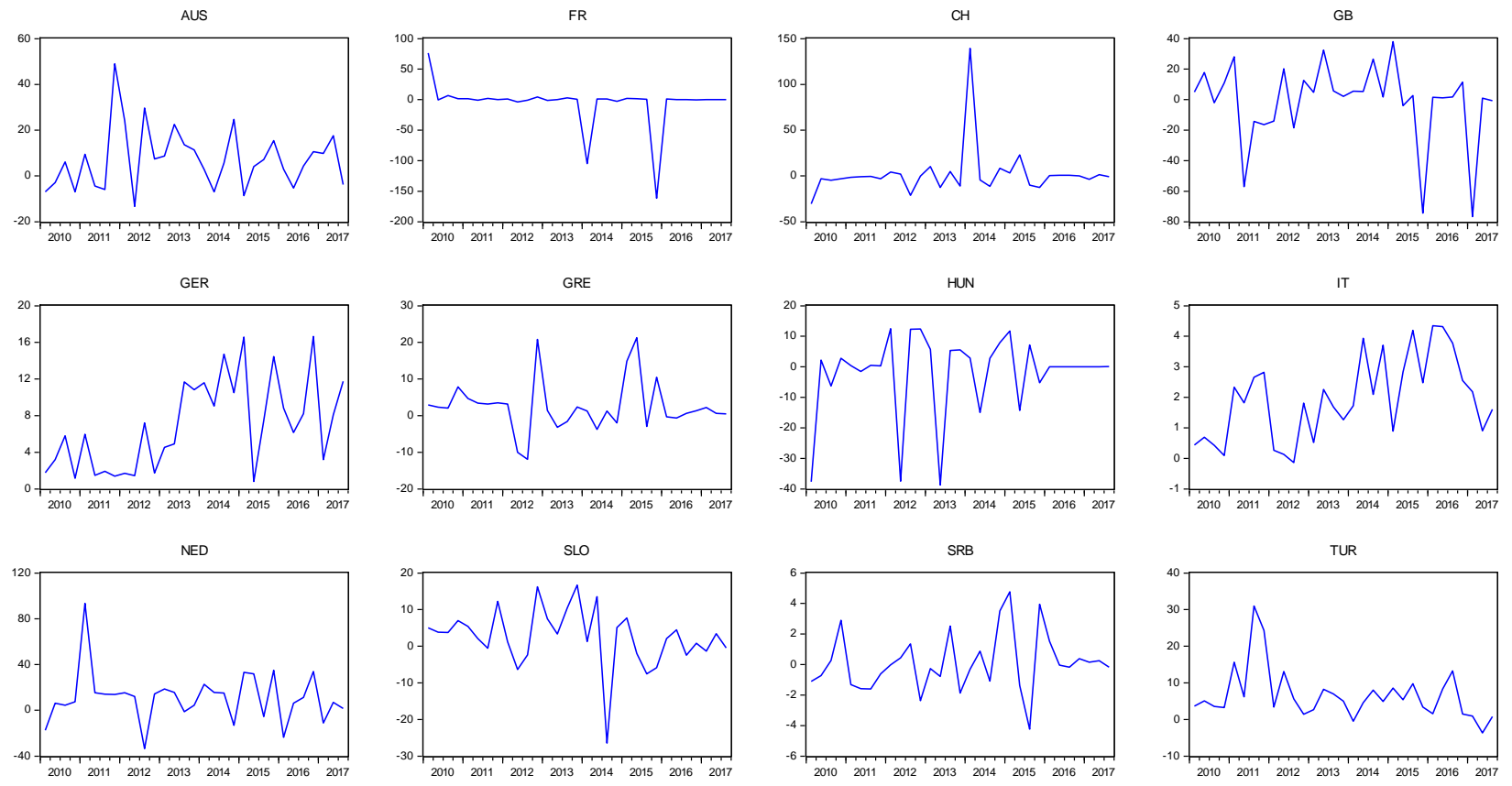

Figure 3- Cross Section Graph Countries which are main resource of FDI inflows in North Macedonia

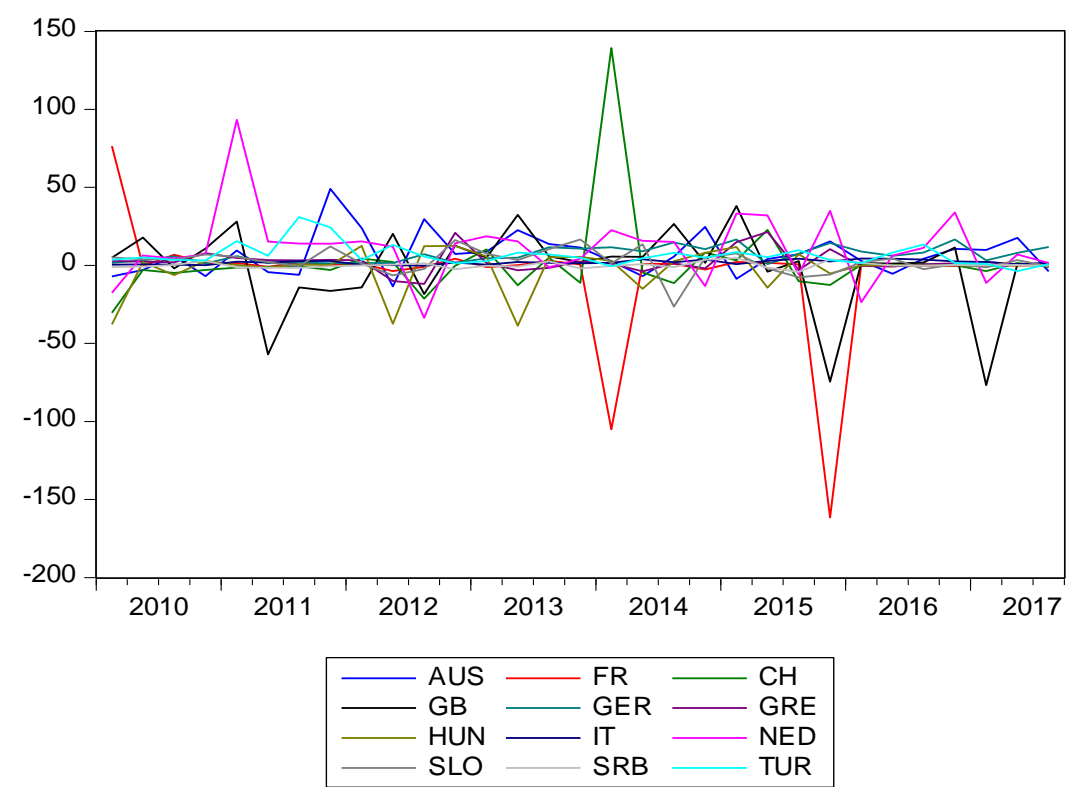


ISSN 2661-2666( Online) International Scientific Journal “Monte” DOI : $\underline{10.33807 / \text { monte.1.201904235 }}$ ISSN 2661-264X (Print)

Figure 5- Real GDP of Macedonia and its components (expenditure method), quarterly data 2010-2017

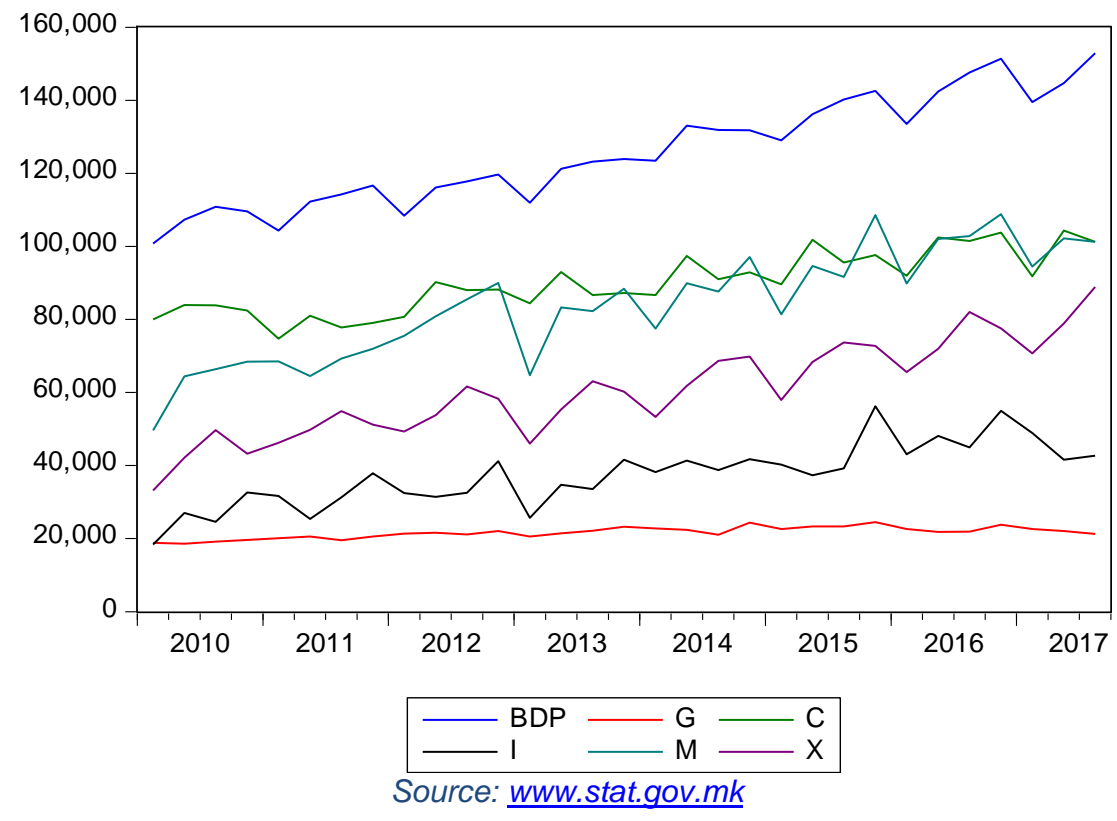

\section{Reference}

1. Fiti T., Ekonomija, Kultura, Skopje, 2016.

2. Risteski S., Tevdovski D., Trpkova M., Analiza na vremenski serii, Ekonomski Fakultet, Skopje, 2012.

3. Pena D., Time Series Analysis, work in progress, 2007.

4. http://europa.eu/rapid/press-release MEMO-18-3405 en.htm

5. www.stat.gov.mk

6. Western Balkans Regular Economic Report, Spring 2018, www.worldbank.org

7. OECD report, FDI in figures, www.OECD.org 